\title{
Insects as food and feed, a new emerging agricultural sector: a review
}

\author{
A. van Huis \\ Laboratory of Entomology, Wageningen University E Research, Droevendaalsesteeg 1, Wageningen 6708 PB, the Netherlands; \\ arnold.vanhuis@wur.nl
}

Received: 30 March 2019 / Accepted: 28 May 2019

(c) 2019 Wageningen Academic Publishers

OPEN ACCESS C(1) R(2) REVIEW ARTICLE

\begin{abstract}
During the last five years the scientific knowledge on insects as food and feed has been growing exponentially. At the same time, the industrial sector is increasingly engaged in rearing, processing and marketing of edible insects. Considerable attention is given to the black soldier fly as it can convert organic waste streams and transform it into several feed, food and industrial products. The farming of insects has an environmental impact which is lower than that of livestock species. The profitability of industrial production of insects as feed depends very much on the availability and applicability of cheap non-utilised side-streams. Microbial communities and their relationship with insects deserve full attention as it may help in the conversion of organic side streams of low economic value. Nutrition and health benefits for animals and humans need further exploration, also considering that insects have the largest anti-microbial peptide reservoir of all animals. Plant health can also be promoted by using chitincontaining leftover substrates as fertiliser. As insects have only recently been considered as food or feed, legislation trails developments. Therefore, politicians need to be assured that rearing and processing techniques are such that insect products are guaranteed free of chemical and microbial contaminants. Consumers are becoming more and more aware that insects as food are a viable option. Insects need to be processed into ingredients, that can be applied for safe and appetising products. The insect sector is maturing fast, but still faces many challenges, which can only be met when all stakeholders closely cooperate.
\end{abstract}

Keywords: edible insects, insects as food and feed, black soldier fly, nutrition, health, environment, industrial production, food safety, consumer attitudes, processing

\section{Introduction}

Insects as food and feed are receiving much attention lately. This is exemplified by the increasing numbers of scientific publications and private enterprises engaged in producing insect products. This review is intended to cover recent developments in this field and to indicate how these contribute to a new emerging sector of insects as food and feed.

It is very likely that early humans already ate insects (Van Huis, 2017). The general notion that edible insects are either a fall-back food or a food used only in marginal environments has been questioned (Lesnik, 2017). Recent evidence suggest that 1.8 million years ago insects in Tanzania were a major food source (Heriot-Watt University, 2018). Primates used the enzyme acidic mammalian chitinase to digest the chitin in insect exoskeletons, which have long been considered indigestible (Janiak et al., 2018). There is a general gradient pattern in reduction of edible insects with increased latitude (Lesnik, 2017), probably because in tropical regions insects are more abundant and easy to harvest (Van Huis, 2018).

The practise of eating insects in different parts of the world has been extensively reviewed (Bergier, 1941; Bodenheimer, 1951; DeFoliart, 2002). It has been termed entomophagy by western people, denoting a peculiar habit of eating a strange food (Evans et al., 2015). Gradually interest in the western world started to emerge of insects as food (Durst et al., 2010; Le Gall and Motte-Florac, 2016; Motte-Florac and Thomas, 2003; Paoletti, 2005), but often the focus was on the consumption of insects by people in the tropics. Also the many publications on edible insects by Julietta 
Ramos Elorduy (Pino Moreno, 2016) in Mexico and the one by Malaisse (1997) in central Africa, served that purpose. The publication by FAO and Wageningen University \& Research (Van Huis et al., 2013) indicated that insects are a viable food and feed option, not only for people in the tropics but also for people elsewhere (Vantomme, 2017). This prompted the recent publications on exploiting insects as food and feed globally (Dossey et al., 2016; Halloran et al., 2018a; Van Huis and Tomberlin, 2017b). National and international conferences on the topic are now being organised.

The question one may ask is why this food source was ignored for so long outside the tropics. Several reasons have been put forward: (1) low availability of small insects (only a part of the year) in temperate zones (Van Huis, 2017); (2) in agriculture insects are considered pests (Van Huis et al., 2013; p. 39); and (3) low esteem for insects, cultural conditioning and prejudice (Bequaert, 1921; DeFoliart, 1999; Looy et al., 2014). It is often not realised that the ecological services of insects are immense. Noriega et al. (2018) classified the services as provisioning (e.g. medicine, nutrition, industrial), regulating (e.g. biological control, pollination), supporting (e.g. decomposition, dung removal, recycling, seed dispersal), and cultural (e.g. bio-indicators, recreation, religion and spiritual values). Let us just mention the value of pollination (235-577 billion US\$ annually) (IPBES, 2016) and natural biological control (thousands of natural enemies keeping potential pests at non-damaging levels at an estimated value of 400 billion US\$ per year (Van Lenteren, 2006). We will concentrate on the supporting services (nutrition) and then only as food for humans or pets, either by consuming insects directly or through production animals (fish, poultry or pigs).

\section{Interest growing rapidly}

The academic interest of using insects as food or feed is exponentially increasing. I searched in the Web of Science for 'edible insects', 'black soldier fly' (or its Latin name Hermetia illucens) as an example of 'insects as feed', and 'mealworm' (and 'edible') as an example of 'insects as food' and found the largest increase occurring after 2015 (Figure 1).

More than 2000 species are consumed by humans (Jongema, 2017), mainly in tropical countries. If we consider which insect species are reared in the western world for food, it turns out these are species that were reared already in order to feed house pets, including reptiles and amphibians. These insects involved are: (1) mealworms - yellow mealworm (Tenebrio molitor), the lesser mealworm (Alphitobius diaperinus), the superworm (Zophobas morio); (2) crickets, mainly the house cricket (Acheta domesticus), but also the tropical house cricket or banded cricket (Gryllodes sigillatus) and the two-spotted cricket (or African or Mediterranean field cricket) (Gryllus bimaculatus); (3) several locust species such as the migratory locust (Locusta migratoria) and the desert Locust (Schistocerca gregaria); and (4) others as by-products from the silk industry (pupae of the domesticated silk worm Bombyx mori) or from beekeeping (the drones) (Ambühl, 2017). If we consider insect species as feed we find also mealworms but in addition, the black soldier fly and to a lesser extent the house fly (Musca domestica) are targeted. Both can be reared on organic side streams, with the first one on most kinds of substrates.

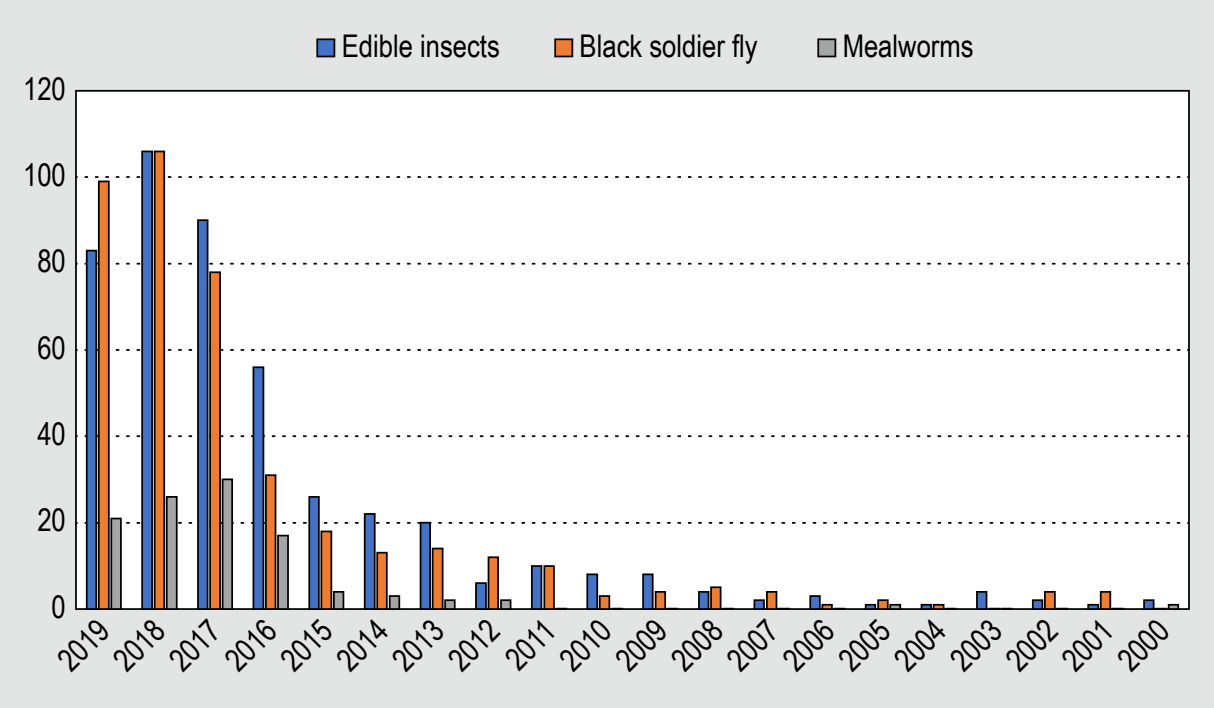

Figure 1. Number of published articles according the Web of Science using 'edible insects', 'black soldier fly' or 'Hermetia illucens', and 'mealworm' and 'edible' (1 July 2019). 
The number of companies in the world working on insects as food and feed, not including insect industry organisations and insect advocacy organisation, is estimated in April 2019 to be more than 250 (BugBurger, 2019). Some of them have received millions of dollars as investment (Feed Navigator: www.feednavigator.com).

\section{Black soldier fly}

Why is there such a tremendous interest in the black soldier fly the last few years? For example, during the 'Insects to Feed the World' conference May 2018 in Wunan China, 40\% of the presentations and posters were about this species. One of the earliest records on $H$. illucens have been in the forensic entomology, an article by Dunn (1916) a hundred years ago on flies found in a human cadaver. One of the first articles on the use of the black soldier fly as feed were for poultry (Hale, 1973) and aquaculture (Bondari and Sheppard, 1981). One of the first articles dealing with the black soldier fly as biowaste converter came a thirteen years later (Sheppard et al., 1994), although their role in reducing manure accumulation (Tingle et al., 1975) and house fly populations in manure (Furman et al., 1959) was already known. Most of these publications came from Georgia, USA. The world distribution of the black soldier fly is given by Rocha Oliveira et al. (2015). The species probably originates from the tropics and subtropics of both Americas (very likely South America), and became by man's activities widespread all over the world (excluding colder areas) (Roháček and Hora, 2013).

Tomberlin et al. (2015) made an appeal to scientists, policy makers, government officials and food production representatives to create legal opportunities for this promising and sustainable resource to be explored and ultimately implemented. Researchers and entrepreneurs affiliated with universities and industries, respectively, from 18 nations distributed across North and South America, Europe, Asia, Africa and Australia contributed to the development of this article. The recent interest of the black soldier fly is not only academic but also commercial considering the number of companies worldwide that are now producing the insect. There are very large companies supported by large investments. However, there are also smaller ones that often need to organise themselves in cooperatives in order to be able to be competitive with the large ones. What are the benefits of using this insect? One the major advantages is that it can thrive on several organic side streams, including manure and catering waste, although those are not yet allowed to be used in the European Union. This list of organic side streams that can be used is large (Van Huis and Tomberlin, 2017a), and other ones are continuously added (Beskin et al., 2018; Moula et al., 2018; Rehman et al., 2017; Xiao et al., 2018). This of course fits well in the policy of a circular economy now adopted as a sustainable development strategy in
European and Chinese policy making (Ranta et al., 2018). Biodegradation can be the purpose, such as in China where manure and catering waste are targeted (Zhang et al., 2020). However, bioconversion or biotransformation are more often envisioned. Producing feed for pets, fish, poultry and pigs is then intended. In the European Union (IPIFF, 2019), black soldier fly larvae and prepupae when reared on materials of vegetal origin are allowed as pet food and since mid-2017 also as fish feed. It is expected that in the next few years it will be allowed for use in pig or poultry feed. Insect-derived fats are allowed as well as live insects. Legislation must be adapted as the original prohibition was the consequence of the mad cow disease in which it was stipulated that animal by-products (insects and their derived products but excluding live insects) are not allowed to be fed to farmed animals. However, likely nobody realised at that time that insects, being animals, could be used as feed. However, it should be realised that when organic waste streams are used as feed, they may contain contaminants, such as bacteria, mycotoxins, heavy metals as well as pesticide residues (Pinotti et al., 2019).

Research is conducted on the microbial community of the black soldier fly not only for optimising the industrial rearing, but also whether it may yield anti-microbials in feed, that can be used in pharma (De Smet et al., 2018). Health benefits of using the black soldier fly have been shown for pigs (e.g. antibacterial effects in prepupal fat against D-streptococci) (Spranghers et al., 2018) and fish (e.g. elevated bacterial diversity and abundance of lactic acid bacteria, which is a potential indicator of improved gut health of rainbow trout) (Huyben et al., 2018).

Left-over substrate can be used as fertiliser (Putra et al., 2017; Rosmiati et al., 2017; Xiao et al., 2018). Chitosan, a derivate of chitin, triggers plant growth and induces plant defence (Sharp, 2013), e.g. providing antifungal and nematocidal activity in fruits and vegetables (Sharif et al., 2018). Wang and Shelomi (2017) discuss their potential use in human foods by processing milled larvae into textured protein. Technological applications are also possible. Protein fractions can be used as raw material for bioplastics (Leni et al., 2017) and protein-based materials, while lipids can be used as bio-lubricants and biofuel (Alipour et al., 2019). From a commercial point of view this is interesting. First because polluted larvae can be used and second because the conversion to high value protein material may be economically more interesting than producing animal feed. Chitin and its derivate chitosan can be used to produce nanofibers (Zimri, 2018).

\section{Environment}

According to Springmann et al. (2018) the global food system is a major driver of environmental burdens; between 2010 and 2050 this could increase by $50-90 \%$ in the absence 
of technological changes and mitigation measures. For example, the indicate that it is possible to reduce greenhouse gas emissions from 187 to $90 \%$ by using a flexitarian diet. Livestock production is considered among the most ecologically harmful of all anthropogenic activities with massive direct and indirect contributions to global warming (72-78\% of total agricultural emissions). This is due to low feed-conversion efficiencies, enteric fermentation in ruminants, and manure-related emissions (Gerber et al., 2013). This causes widespread eco-degradation in terms of land degradation, loss of biodiversity, global warming and stress on water and soil resources (Tabassum et al., 2016). That is why a lot of attention is now paid to alternative food proteins such as plant proteins, cultured meat, insects, and micro-algae and macro-algae (Loveday, 2019). This review deals only with insects.

The environmental effects of insects as food and feed have recently been reviewed with reference to insects collected from nature and when reared (Van Huis and Oonincx, 2017). This review focuses on insects when reared.

A life cycle assessment is a widely accepted method to quantify greenhouse gas (GHG) emissions, and other environmental parameters, such as land or fossil energy use. Parameters are then quantified along the entire life cycle of a product. This is called an attributional life cycle analysis. Using such a life cycle analysis approach, mealworm had lower greenhouse gas emissions, and used less land and water than common production animals (Miglietta et al., 2015; Oonincx and de Boer, 2012). However, benefits can be lower than expected when alternative uses of organic side streams are taken into account, which has been termed 'consequential life cycle analysis' (Van Zanten et al., 2018). Thévenot et al. (2018) concluded that the environmental impact (energy, $\mathrm{CO}_{2}$-eq climate change, acidification potential, eutrophication potential and land use) of producing mealworms needs to be lower in order to perform better than with soybean or fishmeal. Tallentire et al. (2018) looked at the environmental burdens of alternative proteins in the total feed required by a chicken. Mealworms scored better than soybean for greenhouse gas emissions, phosphorus excretion and land use, but not for nitrogen excretion.

Perednia et al. (2017) compared the production of carbonbased greenhouse gases (direct emissions) from food waste by using either black soldier fly larvae or aerobic microbial decomposition. The larvae were able to consume it in seven days, while decomposition required 45 days. In the first case $29 \%$ of the carbon initially present within the system was lost to the atmosphere in the form of $\mathrm{CO}_{2}$, compared to $49 \%$ in the second case. In this case the black soldier fly larvae converted $41 \%$ of the feed carbon into body mass in the forms of protein, edible oil, and chitin.
The necessity for innovations to lower environmental impacts for insect products was mentioned by several authors (Berggren et al., 2019; Halloran et al., 2018b). To reduce environmental impact, upscaling and the use of alternative energy sources for processing was mentioned by Smetana et al. (2019), but for them the most crucial factor was considered to be the availability of non-utilised (not for animal feed) side-streams.

Besides, it is possible to use organic side streams as feed for the insects. Bosch et al. (2019) reviewed forty articles dealing with environmental impact (global warming potential, energy use, and land use) of manure, catering waste or municipal waste conversion by black soldier fly larvae. The impact was lower than that of fishmeal and soy, but not when larvae converted substrates which contained food and feed products such as sorghum and DDGS (dried distillers' grains with solubles).

Biowaste treatment can be a solution to waste management while at the same time providing a protein source. Black soldier fly larvae can be used to treat a variety of organic side streams including municipal waste (Lalander et al., 2019; Sarpong et al., 2018). In Indonesia, the black soldier fly was used for biowaste treatment which resulted in low direct GHG emissions compared to composting, while global warming potential was reduced (Mertenat et al., 2019). The black soldier fly is also able to degrade residual antibiotics, such as tetracycline in manure, which poses risks to ecosystems and public health (Cai et al., 2018) and pesticides (Lalander et al., 2016).

In a review on alternative feed ingredients for livestock, Pinotti et al. (2019) concluded that insects have excellent potential. This mainly because of insects' capability to upgrade food waste biomass. The type of waste material does not seem to influence the protein content and has only an effect on the fat and ash concentration. According to the authors, insects products can meet high quality and safety standards when produced in line with the criteria set by major feed/food authorities.

However, the production of the insect products needs to be more efficient. Although trading prices of insect products have come down, the lesser mealworm is still six times and the black soldier fly nine times more expensive per unit of protein then soymeal (Pinotti et al., 2019).

Styrofoam, expanded polystyrene foam, such as disposable cups and boxes, or cushioning material in packaging, have been proposed for degradation by the yellow mealworm. However, although the foam feeds can maintain the insect's life and produce eggs, it was not economically feasible (Nukmal et al., 2018). Tenebrio obscurus has also been proposed as a likely candidate to be able to degrade plastics (Peng et al., 2019). 


\section{Industrial production}

One of the major problems with insect production is the high production costs as they must compete with the common feed (soy and fishmeal) and food products (ABN AMRO/BOM, 2016). This has to do with the labour costs involved and many companies are engaged in automation processes (Meuwissen, 2011). Patents have been filed on different aspects of the automation processes. Examples or patents filed in 2018 are: the light regime, separating insects from the substrate, water delivery systems and processing (US patent applications: 0065152, 0220632, 0271056, 0360008, respectively). However, the technologies developed after a lot of trial and error are often very simple and easy to copy, which is why companies are very secretive about their production processes. Another significant cost factor is the substrate.

Organic side streams of low economic value can be fed to insects but when crickets were fed on a diet largely consisting of straw, they hardly survived (Lundy and Parrella, 2015). However, the black soldier fly was able to digest rice straw (Manurung et al., 2016). Conversion could be enhanced by using bacteria (Rehman et al., 2019) as was demonstrated by Gao et al. (2019a) with fermented maize straw. Diverting food scraps from landfills to feed animals is recommended but often restricted by laws and regulations (Leib et al., 2016).

When insects are used as feed, two conversion cycles are needed: from organic products to insects and then from insects (as feed) to production animals. With the interest in the circular economy worldwide, the upcycling of lowopportunity-cost feed (food waste, food processing byproducts, grass resources) is being investigated in order to make them more fit as feed directly for production animals (Van Hal et al., 2019), among others by enzymatical digestion processes (Jinno et al., 2018). According to the author, this will make processing of organic waste streams more expensive and therefore economically more challenging to valorise use of insects.

A major question for insect producers is what kinds of waste streams can be used which are not currently utilised for livestock production. Negative value waste streams exist such as manure, and urban and catering waste, but the insect product is then often legally not allowed to be used as feed. Maybe the pros and cons of this policy need further evaluation (Van Huis, 2019). Also the larvae may not perform well, for example because of long development times when reared on manure (Oonincx et al., 2015) or high mortality when reared on straw (Lundy and Parella, 2015). What about when high quality feed stuff would be used for the first larval stages as very little is needed at this early phase of exponential growth and subsequently feed them on low-quality waste streams afterwards? However, changing substrates may not work as black soldier fly larvae have a close association with microbes (Klammsteiner et al., 2018; Wynants et al., 2019a). They probably change the microbial community depending on the nutrient source (Bruno et al., 2019; Jeon et al., 2011) and with that the chemical composition of the substrate (Myers et al., 2008). An innovative solution could be to convert lignocelluloserich organic wastes (such as dairy and chicken manure) by using lignocellulotic exogenous bacteria (Rehman et al., 2019). These authors assume that the structural and chemical modification of the fibres are beneficial to the associated gut bacteria; it promoted larval growth and the reduction of waste. Co-digestion of black soldier fly with microorganisms has also been done with Bacillus subtilis on chicken manure (Xiao et al., 2018) and Lactobacillus buchneri on soybean curd residue (Somroo et al., 2019).

Another possibility is to use different insect species for biodegradation, e.g. corn stover can be degraded first by yellow mealworm larvae followed by the black soldier fly larvae, using the residues produced during the first stage (Wang et al., 2017). Maybe it is also possible to mix lowquality waste streams with high-quality ones. Methods should be environmentally and economically competitive to other uses of waste streams such as the conversion into bioenergy and bio-based products (Gontard et al., 2018). For example, food waste can also be converted to, e.g. phytochemicals, bioactive compounds, food supplements, dietary fibres, bio-pigments and colorants, emulsifiers, edible and essential oils, bio-preservatives, biofertilisers, biofuels, and single cell proteins (Gunjal, 2019; Tamer and Çopur, 2014).

Concerning the insects, probably a lot can be achieved with genetic improvement, considering that insects as mini-livestock is new while in common production animals breeding has been going on for more than 70 years (Harris and Newman, 1994). Insects have a short life cycle, from about 10 days for the house fly to two months for mealworms, while for common production animals it is from six months for chickens to two years for cows. This means that there are better opportunities to genetically improve insects than common production animals. Eight years selection in yellow mealworm led to increases of pupal size, growth rate, fecundity and feed conversion rates compared to the ancestral stain, although survival was lower (Morales-Ramos et al., 2019). Also, it may be possible to select lines of black soldier fly which could handle certain types of organic side-streams (Fowles and Nansen, 2019).

\section{Nutrition, health and acceptability}

The possible health effects of insects as food for humans or feed for animals besides there nutritional value, have been summarised by Roos and Huis (2017) and Gasco et al. (2018), respectively. 


\section{Humans}

The consumption of insects in the western world often is often limited to the occasional snack (House, 2019). However, what if they could be added to staple foods to reach a larger proportion of the population? At the same time, it could add more essential amino acids to the diet and protein-enrichment of staple foods is considered a challenge for the food industry. When mealworms were added to bread (5 and $10 \%$ substitution of wheat), technological features were not affected, and the protein content was enriched (Roncolini et al., 2019). Of course, this would only be environmentally beneficial if people for this reason would consume less meat. With this experiment the feasibility to scale up to industrial level was demonstrated, although safety issues need further consideration.

As a general strategy it is has been tried to increase the acceptability of insects by incorporating them in common food items, e.g. mealworm larvae and silkworm pupae (Kim et al., 2016) or crickets (Keto et al., 2018) in sausages, crickets in energy, protein bars and pork pâté (Adámek et al., 2018; Smarzyński et al., 2019), and termites (Kinyuru et al., 2009) and crickets (Alemu et al., 2016, 2017; Pambo, 2018; Pambo et al., 2018) in buns, and pastas (Enwemiwe and Popoola, 2018; Lombardi et al., 2018).

Insects are also used in food fortification programmes by adding them for improvement of micronutrient nutrition. It is often a health policy to reduce the number of people with dietary deficiencies within a population. For example, in order to treat and prevent malnutrition in infants and children, fortified blended food products have been proposed by addition of products containing arthropods (Michaelsen et al., 2009): spiders in Cambodia (Skau et al., 2015), caterpillars in the Democratic Republic of Congo (Bauserman et al., 2015a,b), and crickets (Homann et al., 2017) and termites (Konyole et al., 2012) in Kenya. This is often to combat iron deficiency anaemia which affects more than a quarter of the children (Lopez et al., 2016). Many insect species have shown not only to have a high concentration of iron but also of zinc (Mwangi et al., 2018).

An interesting development is to change rearing condition such that it increases the nutritional quality of the insects, e.g. by adding linseed (a source of n-3 fatty acids) to the diet (Oonincx et al., in press) or by exposing the insects to ultraviolet radiation (synthesis of vitamin D) (Oonincx et al., 2018). Dietary proteins and protein-derived peptides may improve human health, e.g. peptides derived from lesser mealworm larvae can inhibit enzymes, that play a role in glucose metabolism, and thus in the management of type 2 diabetes (Lacroix et al., 2019). There may also be positive effects of insect consumption on the microbiota of the human gut as was shown by Stull et al. (2018) for the banded cricket.

\section{Animals}

When broiler chicks were administered yellow mealworm and super mealworm larvae as alternatives to antibiotics in broiler chicks, cecal Escherichia coli and Salmonella contents were reduced, while serum IgG and IgA levels improved (Islam and Yang, 2017). This was attributed to combined effects of the chitin content of insect larvae and probiotics. This may also change the perception of the lesser mealworm as a pest in commercial poultry farms, where it serves as reservoir and vector for many pathogens (Rumbos et al., 2019).

It is known that black soldier fly (Erickson et al., 2004), but also the house fly (Nordentoft et al., 2017) reduces pathogenic bacterial strains in poultry manure. Salmonella enterica serovar Gallinarum is a pathogen, causing typhoid fever in chickens. Inclusion of black soldier fly in the feed stimulates the immune response in broiler chickens (Ebertz, 2019). The reason was unknown. However, overall, adding $0.2 \%$ chitosan in the diet did already reduce colonisation of $S$. enterica serovar Typhimurium in broiler chicks (Menconi et al., 2013). The use of black soldier fly larvae in reducing pathogens is more sustainable than the use of agents such as antibiotics. However, it is unknown which are the components in the larvae responsible for the observed immune system enhancing effect.

Melanin, a phenol compound, contributes to dark colour of insect cuticle and is another bioactive compound. It is used for treatment and prevention of hepatic diseases, stress, and tumours (Nekrasov et al., 2018). The melanin found in the black soldier fly is eumelanin, likely with a broad range of antibacterial and antifungal activities (Ushakova et al., 2018). The maximum melanin content was detected in the pupae, while the synthesis was most observed at the prepupa stage. In pupae, it is mostly associated with lauric acid with a proportion of $80 \%$ in melanin-chitosan complex (Ushakova et al., 2017).

\section{Food safety, legislation, insect welfare}

\section{Allergy}

Patients allergic to crustacean or house dust mite have shown cross-reactivity against the grasshopper Sphenarium mexicanum, the desert locust, the field cricket, the house cricket, the yellow mealworm (Pali-Schöll et al., 2019; Sokol et al., 2017; Srinroch et al., 2015; Verhoeckx et al., 2013, 2014). The major cross-reactive proteins are tropomyosin and arginine kinase, well known allergens in arthropods. Food processing can reduce the risk of cross-reactivity and allergenicity of edible insects (Pali-Schöll et al., 2019; Van Broekhoven et al., 2016). To reduce allergenic risk, insect products need to be properly labelled. 


\section{Chemical and microbial contaminants}

\section{Pathogens}

Whether Salmonella sp. could be detected in yellow mealworm larvae depended on the level of contamination in the wheat bran (Wynants et al., 2019b). Edible insects may contain antibiotic resistance genes but this is comparable to other food items (Vandeweyer et al., 2019). Feed may contribute to the occurrence of antibiotic resistance genes and/or antibiotic-resistant microorganisms in yellow mealworm larvae (Osimani et al., 2018). This means that regular microbial monitoring on pathogens of substrates and the larvae is required and the survival of the pathogens should be studied after subsequent processing steps.

\section{Mycotoxins}

The question is how insects deal with contaminants, such as mycotoxins, when grown on diets composed of organic by-products. When diets were contaminated with the mycotoxin deoxynivalenol, yellow mealworm larvae developed normally and degraded the mycotoxin (Van Broekhoven et al., 2017) to concentrations below regulatory limits for food or feed (Sanabria et al., 2017). What is the potential of mycotoxins to accumulate in larvae of the lesser mealworm and the black soldier fly (Camenzuli et al., 2018)? When feed was spiked with aflatoxin $B_{1}$, deoxynivalenol, ochratoxin A or zearalenone, and as a mixture, none of the mycotoxins accumulated in the larvae and were only detected in black soldier fly larvae at very low levels. Both insect species excreted or metabolised the four mycotoxins present in their feed. In another study (Purschke et al., 2017a) also no accumulation of aflatoxins $B_{1} / B_{2} / G_{2}$, deoxynivalenol, ochratoxin $A$, and zearalenone was found in black soldier fly larvae However, the toxicity of the resulting metabolites needs to be further investigated. Ochoa-Sanabria (2019) proposed to feed mycotoxincontaminated wheat to yellow mealworm larvae in order to generate a safe protein replacement for animal feed.

\section{Pesticides}

The accumulation of insecticides (chlorpyrifos, chlorpyrifosmethyl, pirimiphos-methyl) was studied in black soldier fly larvae when the contaminants were spiked in the feed (Purschke et al., 2017a). Pesticides did neither accumulate in the larvae nor affected larval growth. Lalander et al. (2016) also could not find bioaccumulation, when two fungicides (azoxystrobin, propiconazole) were spiked in the substrate.

\section{Heavy metals}

Heavy metal contamination in the diet of black soldier fly impaired larval growth and $\mathrm{Cd}$ and $\mathrm{Pb}$ accumulated in the larval body, indicating a food safety risk (Purschke et al., 2017a). Diener et al. (2015) also found Cd accumulation in the larvae of this insect species, while $\mathrm{Pb}$ and $\mathrm{Zn}$ were less critical. When heavy metals $(\mathrm{Ca}, \mathrm{Cu}, \mathrm{Pb}, \mathrm{Zn})$ were studied in the yellow mealworm and the superworm, $\mathrm{Pb}$ was found below detection limits, but the other metals showed high contents with $\mathrm{Ca}$ exceeding sanitary limits, making them unsuitable for consumption (Mlček et al., 2017).

\section{Pharmaceuticals}

Antibiotics are commonly used in livestock and poultry farming. Richmond et al. (2018) detected 60 pharmaceutical compounds in aquatic invertebrates and riparian spiders in six streams near Melbourne, Australia. The fate of three pharmaceuticals (carbamazepine, roxithromycin, trimethoprim) was studied by Lalander et al. (2016) using black soldier fly larvae in bio-composting. They observed no bioaccumulation in the larvae. Also, the half-life of these pharmaceuticals but also of two fungicides was shorter in the fly larvae compost than in the control. The antibiotic sulphonamide may occur residually in manure. At low concentration ( $>1 \mathrm{mg} / \mathrm{kg}$ ) there was no effect on larval survival, pupation and eclosion of black soldier fly larvae (Gao et al., 2019b). So, using black soldier fly larvae in composting likely impedes the spread of pharmaceuticals and pesticides into the environment.

\section{Legislation}

Boyd (2019) draws attention to the fact that the United States Food and Drug Administration (FDA) has devoted significant attention to insects as defects in human food, e.g. FDA (2016), but comparatively little attention to insects as human food. She recommends that the FDA should make this distinction, stressing that insects should be considered food in the United States. To her opinion this will facilitate cultural acceptance of the use of insects as food.

To make the expanding insect industry successful and sustainable the legal context should receive considerable attention by regulators, legislators, and policymakers. It impacts consumer attitudes and consumption behaviours (Wilderspin and Halloran, 2018).

The EU Novel Food legislation allows the legalisation of edible insect consumption in Europe (IPIFF, 2019; Pisanello and Caruso, 2018). Market permission is considered a first step and more guarantees to producers and consumer are called for (Belluco et al., 2017; Lähteenmäki-Uutela and Grmelová, 2016).

As to feed, insect proteins are allowed for use in for pets and fur animals in the EU. The following insects are allowed as aqua feed since the mid-2017: the black soldier fly, the common house fly, the lesser mealworm, the yellow mealworm, the house cricket, the banded cricket and the 
field cricket (IPIFF, 2019). The European Commission services are currently exploring the possibilities for proposing a new revision of the feed ban rules in order to authorise pig and insect proteins in poultry feed.

What is not allowed in the EU is to use animal manure, catering waste and former foodstuff (meat and fish) as feed. However, more research may be needed to check whether the use of animal manure should be allowed, considering that there is about 1.4 billion tonnes potentially available for processing each year in the EU (Foged et al., 2011). Manure can be used as fertiliser in agriculture, causing environmental problems, such as odours, soil and water contamination and pollution. Moreover, its storage leads to emissions of methane and carbon dioxide. Biogas production is one of the options (Meyer et al., 2018; Scarlat et al., 2018) producing digestate which can also be used as fertiliser. However, in regions with intensive livestock production, the nutrient content of the soil is very high. Then biogas digestate and surplus manure must be either transported to other areas with nutrient demand or stored for long periods. It is worthwhile to investigate the pros and cons of studying the possibilities of biodegradation and biotransformation of manure by insects and the associated food safety and environmental risks and benefits (Van Huis, 2019).

\section{Consumer attitudes}

Sustainability is becoming an increasingly important consideration for consumers when purchasing food. This is shown by the worldwide increase of the organic market value from 18 billion US\$ in 2000 to 97 billion US\$ in 2017; the highest market share (almost 13\%) in 2017 is in Denmark (Willer et al., 2019). In the EU organic meat in retail sales increased in the EU, e.g. from 2.6 to $5.1 \%$ in the UK and from 2.4 to $3.7 \%$ in France (EC, 2018). Although in Canada, the US, Japan and especially China, meat consumption per capita is in the increase (EC, 2018), beef and pig meat will decline in 15 European countries with about one kg per person from 2018 to 2030 (EC, 2018). For example in the Netherlands, it is already declining: per capita consumption decreased from 77.8 to $76.6 \mathrm{~kg}$ from 2007 to 2017 (Statista, 2019). One of the reasons for the decline is the increasing number of flexitarians, vegetarian and vegans, especially among younger consumers. In France, Germany and the Netherlands, the main reason for not consuming meat substitutes is often the taste of meat, while the main reason for not eating meat is animal welfare (Weinrich, 2018). Americans are more inclined to accept insect food than Indians (Ruby and Rozin, 2019). In this study, the major predictor of potential insect consumption for Americans was disgust, followed by benefits, while for Indians it was benefits, followed by disgust and religion.
Attitudes concerning the eating of insects were studied in Finland among vegans, vegetarians, and omnivores (Elorinne et al., 2019). Non-vegan vegetarians held the most positive attitude toward eating insects, mainly because of sustainability reasons, also an important argument for omnivores. Vegans being most neophobic, considered insect consumption as immoral and irresponsible, but disgust factors did not play a role. However, in Germany more than half of the interviewed vegans and vegetarians tasted insects (Rumpold and Langen, 2019). It remains to be seen whether vegetarians, who ethically object meat-eating, would have moral objections against the consumption of insects (Ruby and Rozin, 2019).

There are many insect products on the market. Lamsal et al. (2018) summarised the properties and applications within the context of the food and feed industry. In Belgium energy bars, energy shakes and burgers with insects scored highest, and the preferred place to buy is the supermarket (Van Thielen et al., 2019). Although most people in that country are aware that there are insect-containing food products, only $11 \%$ tried them, while $32 \%$ that have no experience are willing to try them. Psychological barriers could be reduced for consumers of cricket-flour-containing buns in Kenya by giving them opportunities to taste real products and to provide information (Pambo et al., 2018). The more positive evaluation seems to occur by giving information either pre-tasting (Schouteten et al., 2016) or post-tasting (Suzuki and Park, 2018). The texture and appearance of the insect are perceived as stronger barriers than the taste (Sogari et al., 2018), which is why, as a general product strategy insects are incorporated invisibly into familiar products (Caparros Megido et al., 2016; Wilkinson et al., 2018). Market strategies should be tailored towards the consumer. For example, for insect-based products Onwezen et al. (2019) recommend using affective (feel good) communication methods for those consumers that are not actively engaged in healthy or sustainable diets. Youssef et al. (2019) proposed even more innovative methods in his article 'How to make sustainable foods (like jelly fish) delicious'; the consumers were given multisensorial experiences (using projections and audio means).

\section{Processing and conservation}

How to recover valuable fractions such as proteins and lipids from edible insects and how can they be applied as feed or food ingredients? This has to do with fractionation and extraction of insect components, the characterisation of the fractions in terms of nutritional and techno-functional properties (capacities such as emulsification, foaming and gelation) and the functionality of insect-derived ingredients (Tzompa Sosa and Fogliano, 2017).

The different steps required for processing are described by Rumpold et al. (2017). Decontamination is the first 
step and this can is mostly done by thermal or radiation processes. The second step is drying which can be done by convection, and by contact or radiation. Comminution (grinding or milling) is the next step. However, to facilitate the grinding process a defatting step may be required. One of the problems experienced during grinding of the larvae is browning, either caused either by enzymatic or non-enzymatic factors. The colouring of the larvae was strongest in black soldier fly followed by the yellow mealworm, and was least in the lesser mealworm (Janssen et al., 2019). It depended on the iron content of the larvae impacting phenol oxidase and polyphenols. Browning can be prevented by lowering $\mathrm{pH}$ with sodium bisulphite (Yi et al., 2016) or by blanching (Leni et al., 2019; Mancini et al., 2019).

Defatting, a crucial step, prior to protein extraction can be done by mechanically pressing, and by aqueous and solventbased methods (Soxhlet and supercritical carbon dioxide) methods. For example, the Soxhlet method recovered close to $100 \%$ of the lipids of the yellow mealworm, the lesser mealworm and the house cricket, while with the much cheaper aqueous method, it was 19 to 60\% (Tzompa-Sosa et al., 2014). Supercritical $\mathrm{CO}_{2}$ oil extraction of yellow mealworm larvae achieved a high yield of solvent-free oil and a protein-enriched, solvent-free residue at low extraction temperatures (Purschke et al., 2017b). Using the same method with yellow mealworm larvae and the house cricket followed by separation to fine and coarse fractions by air classification generated three fractions: a lipid fraction of triglyceride oils enriched in essential fatty acids, and fine flavour-intense and coarse chitin-rich powder fractions (Sipponen et al., 2017). Oils from the yellow mealworm oil and the house cricket, obtained by aqueous extraction, all had characteristics desirable for table oils and for oils used as food ingredients (Tzompa-Sosa et al., 2019).

For the extraction of proteins, a number of technologies are available such as electrostatic separation, subcritical water extraction, reverse micelles extraction, aqueous two-phase systems, extraction, enzyme-, microwave-, ultrasound-, pulsed electric energy- and high pressureassisted extraction (Pojić et al., 2018).

The most challenging part is to separate protein from chitin. Chitin can be extracted chemically or biologically via fermentation with microorganisms and enzymes, the latter method being much more environmental friendly (Rumpold et al., 2017). The first method using acid and alkali solutions yielded $4.9 \%$ chitin and $3.7 \%$ chitosan from yellow mealworm larvae (Song et al., 2018). The enzymatic method was explored with black soldier fly prepupae (Caligiani et al., 2018). With Bacillus licheniformis protease a nitrogen solubility of about $60 \%$ was obtained. However, the chitin fraction still had a significant residual protein content.
A possibility to obtain innovative healthy foods enriched with insects could be three-dimensional printing of cereal-based products due to their high content of protein (Caporizzi et al., 2019). Because of the scepticism with respect to eating insects in western countries, it could be useful to improve shape, taste and, in turn, their acceptability.

Cultured meat, in-vitro cultivation of animal cells, is being researched for the last 20 years as a sustainable alternative to the common meat production using slaughtered animals (Stephens et al., 2019). For the first time it has now been proposed to use insect cell cultures instead of mammalian or avian cell cultures as they seem to require fewer resources and are more resilient to changes in environmental conditions (Rubio et al., 2019).

During processing and storage food safety needs to be assured. When studying microbial dynamics during rearing, processing, and storage of the cricket G. sigillatus, feed appeared to be an important source for the cricket microbiota. (Vandeweyer et al., 2018). A post-harvest heat treatment reduced high microbial numbers, while a heat treatment during processing will likely eliminate endospores. A shelf life of six months was considered safe.

\section{Conclusions}

A new sector of insects as food and feed is emerging. The number of academic publications is growing exponentially. More and more start-ups are engaging in the industry. Some of them are attracting large sums of money, which shows that investors are becoming aware of the business opportunities. Those investments are necessary as a new emerging industry can only thrive by innovations. Production processes must be invented, often from scratch. In order to be competitive, the cost price needs to come down. That has to do with efficiency of production, not only in terms of techniques and methods used in this rapidly evolving industry, but also with the organisms used and the substrate for the insects.

The technology needed to efficiently farm insects is still in a starting phase. What are the challenges and precautions that need to be considered when breeding and maintaining high-quality insect populations for food and feed? This involves techniques typically used in domestic animal breeding programs including maintaining genetically healthy populations by allowing large population sizes, artificially selecting animals for breeding that possess valuable production traits, and allowing natural selection to operate and thereby maintain high fitness and facilitate adaptation to the production environment (Jensen et al., 2017). However, also deliberate selection procedures could result in lines that can deal with certain types of organic side streams. 
The other challenge is to find feed substrates for insects. The organic side streams with a negative value, such as manure, or urban and catering waste, are of interest. There are legal impediments, but it should be investigated to which extent they are justified, i.e. whether chemical and biological contaminants should be considered a real problem for food safety. Also, consideration is to be given to the various purposes for which the products from the insect industry can be used: (1) left-over substrate as fertiliser; (2) the larvae/prepupae as food and feed; (3) edible oils in food and feed applications or oils in cosmetics, bio-lubricants, or biodiesel; (4) proteins in food and feed applications but also the technological applications such as bio-plastics; and (5) the chitin and chitosan in biomaterials and biomedical applications (Elieh-Ali-Komi and Hamblin, 2016; Morganti et al., 2018).

The nutritional benefits of edible insects for both humans and animals need further investigation. Beneficial effects on the immune system and the gut bacteria have been shown. However, we do not know much about the use of the anti-microbial peptides of which insects provides the broadest range. This is of particular importance in view of the increasing occurrence of multidrug resistant pathogens towards conventional antibiotics (Tonk and Vilcinskas, 2017). In the house fly and the black soldier fly the existence of anti-microbial peptides has already been shown (Elhag et al., 2017; Guo et al., 2017). Also, the effects on plant health of using the left-over substrates, containing chitin, as fertiliser need further investigation.

Food safety and legislation requires full attention, as it is logical that in a new emerging industry legislation must catch up with new developments. Therefore, attention to the chemical and biological contaminants must be given. The pros and cons of the insect industry, including insect welfare issues, should be brought to the attention of politicians as has been done in the Netherlands (RDA, 2018).

Regarding consumer attitudes, there was a steep increase in public attention during the last 10 years. In 2007, googling 'edible insects' gave 100 hits for newspapers, magazines, blogs and on television. In 2016, this number had multiplied to 6,070 (Shockley et al., 2017). In a short time, the people have become acquainted with the idea that insects can be eaten. Strategies have been devised in order to convince consumers, as resistance has a lot to do with eating habits, customs and psychology. The biggest challenge is to make people consume insects as staple food rather than as an occasional snack. This entails incorporation in main food items. Processing insects into tasty products is a prerequisite. Price is also an issue. Expenditures can be brought down by automating the production process, identifying and preparing cheap substrates on which the insects are grown, as well as the developing efficient processing technologies.

The sector of insects as food and feed is developing fast. Organisations are being formed to embed the industry in a more conducive environment. The sector can only progress when the insect industry, the academic world, governmental organisations and public society closely cooperate.

\section{Acknowledgements}

Kees Eveleens and reviewers provided helpful comments on the draft manuscript.

\section{References}

ABN AMRO/BOM, 2016. Insectenkweek: kleine sector, grote kansen. ABN AMRO / BOM Marktstudie. Available at: https://tinyurl. com/y2urcb52.

Adámek, M., Adámková, A., Mlček, J., Borkovcová, M. and Bednářová, M., 2018. Acceptability and sensory evaluation of energy bars and protein bars enriched with edible insect. Potravinarstvo Slovak Journal of Food Sciences 12: 431-437.

Alemu, M.H., Olsen, S.B., Vedel, S.E., Kinyuru, J. and Pambo, K.O., 2016. Integrating sensory evaluations in incentivized discrete choice experiments to assess consumer demand for cricket flour buns in Kenya. Department of Food and Resource Economics. IFRO Working Paper 2016/02. University of Copenhagen, Copenhagen, Denmark. Available at: http://okonomi.foi.dk/workingpapers/ WPpdf/WP2016/IFRO_WP_2016_02.pdf.

Alemu, M.H., Olsen, S.B., Vedel, S.E., Kinyuru, J.N. and Pambo, K.O., 2017. Can insects increase food security in developing countries? An analysis of Kenyan consumer preferences and demand for cricket flour buns. Food Security 9: 471-484.

Alipour, N., Vinnerås, B., Gouanvé, F., Espuche, E. and Hedenqvist, M.S., 2019. A protein-based material from a new approach using whole defatted larvae, and its interaction with moisture. Polymers 11: 287. https://doi.org/10.3390/polym11020287

Ambühl, D., 2017. Beezza? The honeybee cook-book: an introduction to harvesting and cooking drones of the honeybee. Skyfood Publishing, Unterterzen, Switzerland, $136 \mathrm{pp}$.

Bauserman, M., Lokangaka, A., Gado, J., Close, K., Wallace, D., Kodondi, K.-K., Tshefu, A. and Bose, C., 2015a. A clusterrandomized trial determining the efficacy of caterpillar cereal as a locally available and sustainable complementary food to prevent stunting and anaemia. Public Health Nutrition 18: 1785-1792.

Bauserman, M., Lokangaka, A., Kodondi, K.-K., Gado, J., Viera, A.J., Bentley, M.E., Engmann, C., Tshefu, A. and Bose, C., 2015b. Caterpillar cereal as potential complementary feeding product for infants and young children: nutritional content and acceptability. Maternal \& Child Nutrition, Suppl. 4: 214-220. https://doi. org/10.1111/mcn.12037

Belluco, S., Halloran, A. and Ricci, A., 2017. New protein sources and food legislation: the case of edible insects and EU law. Food Security 9: 803-814. 
Bequaert, J., 1921. Insects as food. How they have augmented the food supply of mankind in early and recent years. Natural History Journal 21: 191-200.

Berggren, Å., Jansson, A. and Low, M., 2019. Approaching ecological sustainability in the emerging insects-as-food industry. Trends in Ecology \& Evolution 34: 132-138.

Bergier, E., 1941. Peuples entomophages et insectes comestibles: étude sur les moeurs de l'homme et de l'insecte. Imprimerie Rullière, Avignon, France.

Beskin, K.V., Holcomb, C.D., Cammack, J.A., Crippen, T.L., Knap, A.H., Sweet, S.T. and Tomberlin, J.K., 2018. Larval digestion of different manure types by the black soldier fly (Diptera: Stratiomyidae) impacts associated volatile emissions. Waste Management 74: 213-220.

Bodenheimer, F.S., 1951. Insects as human food; a chapter of the ecology of man. Dr. W. Junk Publishers, The Hague, the Netherlands, $352 \mathrm{pp}$.

Bondari, K. and Sheppard, D.C., 1981. Soldier fly larvae as feed in commercial fish production. Aquaculture 24: 103-109.

Bosch, G., Van Zanten, H.H.E., Zamprogna, A., Veenenbos, M., Meijer, N.P., Van der Fels-Klerx, H.J. and Van Loon, J.J.A., 2019. Conversion of organic resources by black soldier fly larvae: legislation, efficiency and environmental impact. Journal of Cleaner Production 222: 355-363.

Boyd, M.C., 2019. Cricket soup: a critical examination of the regulation of insects as food. Yale Law \& Policy Review 36: 17-81.

Bruno, D., Bonelli, M., De Filippis, F., Di Lelio, I., Tettamanti, G., Casartelli, M., Ercolini, D. and Caccia, S., 2019. The intestinal microbiota of Hermetia llucens larvae is affected by diet and shows a diverse composition in the different midgut regions. Applied and Environmental Microbiology 85: e01864-18. https://doi.org/10.1128/ AEM.01864-18

BugBurger, 2019. The eating insects startups: here is the list of entopreneurs around the world! Available at: http://www. bugburger.se/foretag/the-eating-insects-startups-here-is-the-listof-entopreneurs-around-the-world.

Cai, M., Ma, S., Hu, R., Tomberlin, J.K., Yu, C., Huang, Y., Zhan, S., Li, W., Zheng, L., Yu, Z. and Zhang, J., 2018. Systematic characterization and proposed pathway of tetracycline degradation in solid waste treatment by Hermetia illucens with intestinal microbiota. Environmental Pollution 242: 634-642.

Caligiani, A., Marseglia, A., Leni, G., Baldassarre, S., Maistrello, L., Dossena, A. and Sforza, S., 2018. Composition of black soldier fly prepupae and systematic approaches for extraction and fractionation of proteins, lipids and chitin. Food Research International 105: 812-820.

Camenzuli, L., Van Dam, R., De Rijk, T., Andriessen, R., Van Schelt, J. and Van der Fels-Klerx, H., 2018. Tolerance and excretion of the mycotoxins aflatoxin $\mathrm{B}_{1}$, zearalenone, deoxynivalenol, and ochratoxin a by Alphitobius diaperinus and Hermetia illucens from contaminated substrates. Toxins 10: 91. https://doi.org/10.3390/ toxins10020091

Caparros Megido, R., Gierts, C., Blecker, C., Brostaux, Y., Haubruge, É., Alabi, T. and Francis, F., 2016. Consumer acceptance of insectbased alternative meat products in western countries. Food Quality and Preference 52: 237-243.
Caporizzi, R., Derossi, A. and Severini, C., 2019. Cereal-based and insect-enriched printable food: from formulation to postprocessing treatments: status and perspectives. In: Godoi, F.C., Bhandari, B.R., Prakash, S. and Zhang, M. (eds.) Fundamentals of 3D food printing and applications. Academic Press, Amsterdam, the Netherlands, pp. 93-116.

De Smet, J., Wynants, E., Cos, P. and Van Campenhout, L., 2018. Microbial community dynamics during rearing of black soldier fly larvae (Hermetia illucens) and impact on exploitation potential. Applied and Environmental Microbiology 84: e02722-17. https:// doi.org/10.1128/AEM.02722-17

DeFoliart, G.R., 1999. Insects as food: why the western attitude is important. Annual Review of Entomology 41: 21-50.

DeFoliart, G.R., 2002. The human use of insects as food resource: a bibliographic account in progress. Department of Entomology, University of Wisconsin-Madison, Madison, WI, USA. Available at: http://tinyurl.com/4ogh573.

Diener, S., Zurbrügg, C. and Tockner, K., 2015. Bioaccumulation of heavy metals in the black soldier fly, Hermetia illucens and effects on its life cycle. Journal of Insects as Food and Feed 1: 261-270. https://doi.org/10.3920/JIFF2015.0030

Dossey, A.T., Morales-Ramos, J. and Rojas, M.G. (eds.), 2016. Insects as sustainable food ingredients: production, processing and food applications. Elsevier, Amsterdam, the Netherlands.

Dunn, L.H., 1916. Hermetia illuscens, breeding in a human cadaver. Entomology News 27: 59-61.

Durst, P.B., Johnson, D.V., Leslie, R.N. and Shono, K., 2010. Forest insects as food: humans bite back. Proceedings of a workshop on Asia-Pacific resources and their potential for development. February 19-21, 2008. FAO, Regional Office for Asia and the Pacific, Chiang Mai, Thailand.

Ebertz, A., 2019. Insects as a tool against fowl typhoid disease. University of London, London, UK. Available at: http://tinyurl. com/yyyvxg8w.

European Commission (EC), 2018. EU agricultural outlook for markets and income, 2018-2030. European Commission, DG Agriculture and Rural Development, Brussels, Belgium.

Elhag, O., Zhou, D., Song, Q., Aa, S., Cai, M., Zheng, L., Yu, Z. and Zhang, J., 2017. Screening, expression, purification and functional characterization of novel antimicrobial peptide genes from Hermetia illucens (L.). PLoS ONE 12: e0169582.

Elieh-Ali-Komi, D. and Hamblin, M.R., 2016. Chitin and chitosan: production and application of versatile biomedical nanomaterials. International Journal of Advanced Research 4: 411-427.

Elorinne, A.-L., Niva, M., Vartiainen, O. and Väisänen, P., 2019. Insect consumption attitudes among vegans, non-vegan vegetarians, and omnivores. Nutrients 11: E292. https://doi.org/10.3390/nu11020292

Enwemiwe, V.N. and Popoola, K.O.K., 2018. Edible insects: rearing methods and incorporation into commercial food products-a critical review. International Journal of Advanced Research and Publications 2: 38-46.

Erickson, M.C., Islam, M., Sheppard, C., Liao, J. and Doyle, M.P., 2004. Reduction of Escherichia coli O157:H7 and Salmonella enterica serovar Enteritidis in chicken manure by larvae of the black soldier fly. Journal of Food Protection 67: 685-690. 
Evans, J., Alemu, M.H., Flore, R., Frøst, M.B., Halloran, A., Jensen, A.B., Maciel-Vergara, G., Meyer-Rochow, V.B., Münke-Svendsen, C., Olsen, S.B., Payne, C., Roos, N., Rozin, P., Tan, H.S.G., Van Huis, A., Vantomme, P. and Eilenberg, J., 2015. 'Entomophagy': an evolving terminology in need of review. Journal of Insects as Food and Feed 1: 293-305. https://doi.org/10.3920/JIFF2015.0074

Foged, H.L., Flotats, X., Blasi, A.B., Palatsi, J., Magri, A. and Schelde, K.M., 2011. Inventory of manure processing activities in Europe. Technical Report No. I concerning 'Manure Processing Activities in Europe' to the European Commission, Directorate-General Environment, 138 pp. Available at: http://agro-technology-atlas. eu/docs/21010_technical_report_I_inventory.pdf.

Fowles, T.M. and Nansen, C., 2019. Artificial selection of insects to bioconvert pre-consumer organic wastes. A review. Agronomy for Sustainable Development 39: 31. https://doi.org/10.1007/s13593019-0577-z

Furman, D.P., Young, R.D. and Catts, P.E., 1959. Hermetia illucens (Linnaeus) as a factor in the natural control of Musca domestica Linnaeus. Journal of Economic Entomology 52: 917-921.

Gao, Z., Wang, W., Lu, X., Zhu, F., Liu, W., Wang, X. and Lei, C., 2019a. Bioconversion performance and life table of black soldier fly (Hermetia illucens) on fermented maize straw. Journal of Cleaner Production 230: 974-980.

Gao, Q., Deng, W., Gao, Z., Li, M., Liu, W., Wang, X. and Zhu, F., 2019b. Effect of sulfonamide pollution on the growth of manure management candidate Hermetia illucens. PLoS ONE 14: e0216086.

Gasco, L., Finke, M. and Van Huis, A., 2018. Can diets containing insects promote animal health? Journal of Insects as Food and Feed 4: 1-4. https://doi.org/10.3920/JIFF2018.x001

Gerber, P.J., Steinfeld, H., Henderson, B., Mottet, A., Opio, C., Dijkman, J., Falcucci, A. and Tempio, G., 2013. Tackling climate change through livestock - a global assessment of emissions and mitigation opportunities. Food and Agriculture Organization of the United Nations, Rome, Italy.

Gontard, N., Sonesson, U., Birkved, M., Majone, M., Bolzonella, D., Celli, A., Angellier-Coussy, H., Jang, G.-W., Verniquet, A., Broeze, J., Schaer, B., Batista, A.P. and Sebok, A., 2018. A research challenge vision regarding management of agricultural waste in a circular bio-based economy AU - Gontard, Nathalie. Critical Reviews in Environmental Science and Technology 48: 614-654.

Gunjal, B.B., 2019. Value-added products from food waste. In: Gunjal, A.B., Sheshrao, M., Waghmode, Patil, N.N. and Bhatt, P. (eds.) Global initiatives for waste reduction and cutting food loss. IGI Global, Hershey, PA, USA, pp. 20-30.

Guo, G., Tao, R., Li, Y., Ma, H., Xiu, J., Fu, P. and Wu, J., 2017. Identification and characterization of a novel antimicrobial protein from the housefly Musca domestica. Biochemical and Biophysical Research Communications 490: 746-752.

Hale, O.M., 1973. Dried Hermelia iIIucens larvae (Diptera: Stratiomyidae) as a feed additive for poultry. Journal of the Georgia Entomological Society 8: 16-20.

Halloran, A., Flore, R., Vantomme, P. and Roos, N., 2018a. Edible insects in sustainable food systems. Springer International Publishing, Cham, Switzerland.
Halloran, A., Hansen, H.H., Jensen, L.S. and Bruun, S., 2018b. Comparing environmental impacts from insects for feed and food as an alternative to animal production. In: Halloran, A., Flore, R., Vantomme, P. and Roos, N. (eds.) Edible insects in sustainable food systems. Springer International Publishing, Cham, Switzerland, pp. 163-180.

Harris, D.L. and Newman, S., 1994. Breeding for profit: synergism between genetic improvement and livestock production (a review). Journal of Animal Science 72: 2178-2200.

Heriot-Watt University, 2018. Research reveals insects were major food source millions of years ago. Available at: https://phys.org/ news/2018-04-reveals-insects-major-food-source.html.

Homann, A.M., Ayieko, M.A., Konyole, S.O. and Roos, N., 2017. Acceptability of biscuits containing 10\% cricket (Acheta domesticus) compared to milk biscuits among 5-10-year-old Kenyan schoolchildren. Journal of Insects as Food and Feed 3: 95-103. https://doi.org/10.3920/JIFF2016.0054

House, J., 2019. Modes of eating and phased routinisation: insectbased food practices in the Netherlands. Sociology 53: 451-467.

Huyben, D., Vidaković, A., Hallgren, S.W. and Langeland, M., 2018. High-throughput sequencing of gut microbiota in rainbow trout (Oncorhynchus mykiss) fed larval and pre-pupae stages of black soldier fly (Hermetia illucens). Aquaculture 500: 485-491.

Intergovernmental Science-Policy Platform on Biodiversity and Ecosystem (SIPBES), 2016. Summary for policymakers of the assessment report of the Intergovernmental Science-Policy Platform on Biodiversity and Ecosystem Services on pollinators, pollination and food production. Potts, S.G., Imperatriz-Fonseca, V.L., Ngo, H.T., Biesmeijer, J.C., Breeze, T.D., Dicks, L.V., Garibaldi, L.A., Hill, R., Settele, J., Vanbergen, A.J., Aizen, M.A., Cunningham, S.A., Eardley, C., Freitas, B.M., Gallai, N., Kevan, P.G., KovácsHostyánszki, A., Kwapong, P.K., Li, J., Li, X., Martins, D.J., NatesParra, G., Pettis, J.S., Rader, R. and Viana, B.F. (eds.) Secretariat of the Intergovernmental Science-Policy Platform on Biodiversity and Ecosystem Services, Bonn, Germany, pp. 1-28.

International Platform of Insects for Food and Feed (IPIFF), 2019. EU Legislation. IPIFF, Brussels, Belgium. Available at: http://ipiff.org/ insects-eu-legislation.

Islam, M.M. and Yang, C.-J., 2017. Efficacy of mealworm and super mealworm larvae probiotics as an alternative to antibiotics challenged orally with Salmonella and E. coli infection in broiler chicks. Poultry Science 96: 27-34.

Janiak, M.C., Chaney, M.E. and Tosi, A.J., 2018. Evolution of acidic mammalian chitinase genes (chia) is related to body mass and insectivory in primates. Molecular Biology and Evolution 35: 607622.

Janssen, R.H., Canelli, G., Sanders, M.G., Bakx, E.J., Lakemond, C.M.M., Fogliano, V. and Vincken, J.-P., 2019. Iron-polyphenol complexes cause blackening upon grinding Hermetia illucens (black soldier fly) larvae. Scientific Reports 9: 2967. https://doi.org/10.1038/ s41598-019-38923-x

Jensen, K., Torsten, N.K., Heckmann, L.-H.L. and Sørensen, J.G., 2017. Breeding and maintaining high-quality insects. In: Van Huis, A. and Tomberlin, J.K. (eds.) Insects as food and feed: from production to consumption. Wageningen Academic Publishers, Wageningen, the Netherlands, pp. 175-198. 
Jeon, H., Park, S., Choi, J., Jeong, G., Lee, S.-B., Choi, Y. and Lee, S.-J., 2011. The intestinal bacterial community in the food waste-reducing larvae of Hermetia illucens. Current Microbiology 62: 1390-1399.

Jinno, C., He, Y., Morash, D., McNamara, E., Zicari, S., King, A., Stein, H.H. and Liu, Y., 2018. Enzymatic digestion turns food waste into feed for growing pigs. Animal Feed Science and Technology 242: 48-58.

Jongema, Y., 2017. List of edible insect species of the world. Laboratory of Entomology, Wageningen UR, Wageningen, the Netherlands.

Keto, L., Stefanski, T., Isokangas, A., Rautio, P., Rokka, S. and Pihlanto, A., 2018. A pilot study: consumer acceptability of Polish style cooked sausages containing house cricket flour. Suomen Maataloustieteellisen Seuran Tiedote NRO 35. Available at: https:// journal.fi/smst/article/view/73139/35022.

Kim, H.-W., Setyabrata, D., Lee, Y.J., Jones, O.G. and Kim, Y.H.B., 2016. Pre-treated mealworm larvae and silkworm pupae as a novel protein ingredient in emulsion sausages. Innovative Food Science \& Emerging Technologies 38, Part A: 116-123.

Kinyuru, J.N., Kenji, G.M. and Njoroge, M.S., 2009. Process development, nutrition and sensory qualities of wheat buns enriched with edible termites (Macrotermes subhylanus) from Lake Victoria region, Kenya. African Journal of Food and Agriculture Nutrition and Development 9: 1739-1750.

Klammsteiner, T., Walter, A., Heussler, C., Schlick-Steiner, B.C., Steiner, F.M. and Insam, H., 2018. Hermetia illucens (Diptera: Stratiomyidae) larvae in waste valorization and diet-based shifts in their gut microbiome. Available at: https://tinyurl.com/y35nbs9a.

Konyole, S.O., Kinyuru, J.N., Owuor, B.O., Kenji, G.M., Onyango, C.A., Estambale, B.B., Friis, H., Roos, N. and Owino, V.O., 2012. Acceptability of amaranth grain-based nutritious complementary foods with dagaa fish (Rastrineobola argentea) and edible termites (Macrotermes subhylanus) compared to corn soy blend plus among young children/mothers dyads in Western Kenya. Journal of Food Research 1: 111-120.

Lacroix, I.M.E., Dávalos Terán, I., Fogliano, V. and Wichers, H.J., 2019. Investigation into the potential of commercially available lesser mealworm (A. diaperinus) protein to serve as sources of peptides with DPP-IV inhibitory activity. International Journal of Food Science \& Technology 54: 696-704.

Lähteenmäki-Uutela, A. and Grmelová, N., 2016. European law on insects in food and feed. European Food and Feed Law Review 11: $2-8$.

Lalander, C., Diener, S., Zurbrügg, C. and Vinnerås, B., 2019. Effects of feedstock on larval development and process efficiency in waste treatment with black soldier fly (Hermetia illucens). Journal of Cleaner Production 208: 211-219.

Lalander, C., Senecal, J., Gros Calvo, M., Ahrens, L., Josefsson, S., Wiberg, K. and Vinnerås, B., 2016. Fate of pharmaceuticals and pesticides in fly larvae composting. Science of the Total Environment 565: 279-286.

Lamsal, B., Wang, H., Pinsirodom, P. and Dossey, A.T., 2018. Applications of insect-derived protein ingredients in food and feed industry. Journal of the American Oil Chemists' Society 96: 105-123.
Le Gall, P. and Motte-Florac, E., 2016. Savoureux insectes: d'aliment traditionelles à l'innovation gastronomique. Presses Universitaires de Rennes/Institut de Recherche pour le développement, Rennes, France, $500 \mathrm{pp}$.

Leib, E.B., Balkus, O., Rice, C., Maley, M., Taneja, R., Cheng, R., Civita, N. and Alvoid, T., 2016. Leftovers for livestock: a legal guide for using food scraps as animal feed. Available at: https://tinyurl.com/ y2yee3h6.

Leni, G., Caligiani, A., Marseglia, A., Baldassarre, S., Maistrello, L. and Sforza, S., 2017. Fractionation of black soldier fly biomolecules for feed/food or technological applications. Poster valoribio. University of Parma, Parma, Italy.

Leni, G., Caligiani, A. and Sforza, S., 2019. Killing method affects the browning and the quality of the protein fraction of black soldier fly (Hermetia illucens) prepupae: a metabolomics and proteomic insight. Food Research International 115: 116-125.

Lesnik, J.J., 2017. Not just a fallback food: global patterns of insect consumption related to geography, not agriculture. American Journal of Human Biology 29: e22976. https://doi.org/10.1002/ ajhb. 22976

Lombardi, A., Vecchio, R., Borrello, M., Caracciolo, F. and Cembalo, L., 2018. Willingness to pay for insect-based food: the role of information and carrier. Food Quality and Preference 72: 177-187.

Looy, H., Dunkel, F.V. and Wood, J.R., 2014. How then shall we eat? Insect-eating attitudes and sustainable foodways. Agriculture and Human Values 31: 131-141.

Lopez, A., Cacoub, P., Macdougall, I.C. and Peyrin-Biroulet, L., 2016. Iron deficiency anaemia. The Lancet 387: 907-916.

Loveday, S.M., 2019. Food proteins: technological, nutritional, and sustainability attributes of traditional and emerging proteins. Annual Review of Food Science and Technology 10: 311-339.

Lundy, M.E. and Parrella, M.P., 2015. Crickets are not a free lunch: protein capture from scalable organic side-streams via high-density populations of Acheta domesticus. PLoS ONE 10: e0118785.

Malaisse, F., 1997. Se nourir en foret claire africaine: approche ecologique et nutritionnelle. Les Presses Agronomiques de Gembloux, Gembloux, Belgium, 384 pp.

Mancini, S., Fratini, F., Tuccinardi, T., Turchi, B., Nuvoloni, R. and Paci, G., 2019. Effects of different blanching treatments on microbiological profile and quality of the mealworm (Tenebrio molitor). Journal of Insects as Food and Feed 5: 225-234. https:// doi.org/10.3920/jiff2018.0034

Manurung, R., Supriatna, A., Esyanthi, R.R. and Putra, R.E., 2016. Bioconversion of rice straw waste by black soldier fly larvae (Hermetia illucens L.): optimal feed rate for biomass production. Journal of Entomology and Zoology Studies 4: 1036-1041.

Menconi, A., Pumford, N.R., Morgan, M.J., Bielke, L.R., Kallapura, G., Latorre, J.D., Wolfenden, A.D., Hernandez-Velasco, X., Hargis, B.M. and Tellez, G., 2013. Effect of chitosan on Salmonella typhimurium in broiler chickens. Foodborne Pathogens and Disease 11: 165-169.

Mertenat, A., Diener, S. and Zurbrügg, C., 2019. Black soldier fly biowaste treatment - assessment of global warming potential. Waste Management 84: 173-181.

Meuwissen, P., 2011. Insecten als nieuwe eiwitbron - Een scenarioverkenning van de marktkansen. ZLTO projecten, Den Bosch, the Netherlands. 
Meyer, A.K.P., Ehimen, E.A. and Holm-Nielsen, J.B., 2018. Future European biogas: animal manure, straw and grass potentials for a sustainable European biogas production. Biomass and Bioenergy 111: 154-164.

Michaelsen, K.F., Hoppe, C., Roos, N., Kaestel, P., Stougaard, M., Lauritzen, L. and Mølgaard, C., 2009. Choice of foods and ingredients for moderately malnourished children 6 months to 5 years of age. Food and Nutrition Bulletin 30: 343-404.

Miglietta, P.P., Leo, F.D., Ruberti, M. and Massari, S., 2015. Mealworms for food: a water footprint perspective. Water 7: 6190-6203.

Mlček, J., Adamek, M., Adámková, A., Borkovcová, M., Bednářová, M. and Skácel, J., 2017. Detection of selected heavy metals and micronutrients in edible insect and their dependency on the feed using XRF spectrometry. Potravinarstvo Slovak Journal of Food Sciences 11: 725-730.

Morales-Ramos, J.A., Kelstrup, H.C., Rojas, M.G. and Emery, V., 2019. Body mass increase induced by eight years of artificial selection in the yellow mealworm (Coleoptera: Tenebrionidae) and life history trade-offs. Journal of Insect Science 19: 4. https://doi.org/10.1093/ jisesa/iey110

Morganti, P., Danti, S. and Coltelli, M.B., 2018. Chitin and lignin to produce biocompatible tissues. Research in Clinical Dermatology 1:5-11.

Motte-Florac, É. and Thomas, J.M.C., 2003. 'Insects' in oral literature and traditions. In: Colloque internationale Les 'insectes' dans la tradition orale, Villejuif (France), October, 3-6, 2000, Ethnosciences, 11, SELAF, nr. 407, Peeters, Leuven, Belgium, 633 pp.

Moula, N., Scippo, M.-L., Douny, C., Degand, G., Dawans, E., Cabaraux, J.-F., Hornick, J.-L., Megido, R.C., Leroy, P., Francis, F. and Detilleux, J., 2018. Performances of local poultry breed fed black soldier fly larvae reared on horse manure. Animal Nutrition 4: 73-78.

Mwangi, M.N., Oonincx, D.G.A.B., Stouten, T., Veenenbos, M., MelseBoonstra, A., Dicke, M. and Van Loon, J.J.A., 2018. Insects as sources of iron and zinc in human nutrition. Nutrition Research Reviews 31: 248-255.

Myers, H.M., Tomberlin, J.K., Lambert, B.D. and Kattes, D., 2008. Development of black soldier fly (Diptera: Stratiomyidae) larvae fed dairy manure. Environmental Entomology 37: 11-15.

Nekrasov, R.V., Zelenchenkova, A.A., Chabaev, M.G. and Ushakova, N.A., 2018. Dietary additives and bioactive substances: melanine protein-energy additive from Hermetia illucens larvae in nutrition of calves. Agricultural Biology 53: 374-384.

Nordentoft, S., Fischer, C., Bjerrum, L., Heckmann, L.H. and Hald, B., 2017. Reduction of Escherichia coli, Salmonella enteritidis and Campylobacter jejuni in poultry manure by rearing of Musca domestica fly larvae. Journal of Insects as Food and Feed 3: 145-153. https://doi.org/10.3920/JIFF2016.0058

Noriega, J.A., Hortal, J., Azcárate, F.M., Berg, M.P., Bonada, N., Briones, M.J.I., Del Toro, I., Goulson, D., Ibanez, S., Landis, D.A., Moretti, M., Potts, S.G., Slade, E.M., Stout, J.C., Ulyshen, M.D., Wackers, F.L., Woodcock, B.A. and Santos, A.M.C., 2018. Research trends in ecosystem services provided by insects. Basic and Applied Ecology 26: 8-23.
Nukmal, N., Umar, S., Puspita, S. and Kanedi, M., 2018. Effect of styrofoam waste feeds on the growth, development and fecundity of mealworms (Tenebrio molitor). Journal of Biological Sciences 18: 24-28.

Ochoa-Sanabria, C., 2019. Feeding mycotoxin-contaminated wheat to insect larvae (Tenebrio molitor) as a strategy to use Fusariumdamaged grain and generate a safe protein replacement for animal feed. Bulletin de la Société d'entomologie du Canada 50: 31-35.

Onwezen, M.C., Van den Puttelaar, J., Verain, M.C.D. and Veldkamp, T., 2019. Consumer acceptance of insects as food and feed: the relevance of affective factors. Food Quality and Preference 77: 51-63.

Oonincx, D. and De Boer, I., 2012. Environmental impact of the production of mealworms as a protein source for humans - a life cycle assessment. PLoS ONE 7: e51145.

Oonincx, D.G.A.B., Van Keulen, P., Finke, M.D., Baines, F.M., Vermeulen, M. and Bosch, G., 2018. Evidence of vitamin D synthesis in insects exposed to UVb light. Scientific Reports 8: 10807. https:// doi.org/10.1038/s41598-018-29232-w

Oonincx, D.G.A.B., Laurent, S., Veenenbos, M.E. and Van Loon, J.J.A., in press. Dietary enrichment of edible insects with omega 3 fatty acids. Insect Science, https://doi.org/10.1111/1744-7917.12669

Oonincx, D.G.A.B., Van Huis, A. and Van Loon, J.J.A., 2015. Nutrient utilisation by black soldier flies fed with chicken, pig, or cow manure. Journal of Insects as Food and Feed 1: 131-139. https:// doi.org/10.3920/JIFF2014.0023

Osimani, A., Milanovic', V., Cardinali, F., Garofalo, C., Clementi, F., Ruschioni, S., Riolo, P., Isidoro, N., Loreto, N., Galarini, R., Moretti, S., Petruzzelli, A. and Micci, E., 2018. Distribution of transferable antibiotic resistance genes in laboratory-reared edible mealworms (Tenebrio molitor L.). Frontiers in Microbiology 9: 2702. https:// doi.org/10.3389/fmicb.2018.02702

Pali-Schöll, I., Meinlschmidt, P., Larenas-Linnemann, D., Purschke, B., Hofstetter, G., Rodríguez-Monroy, F.A., Einhorn, L., MothesLuksch, N., Jensen-Jarolim, E. and Jäger, H., 2019. Edible insects: cross-recognition of IgE from crustacean- and house dust mite allergic patients, and reduction of allergenicity by food processing. WAO Journal 12: 45-54.

Pambo, K.O., 2018. Assessment of consumer attitudes and motivation to consume foods from edible insects: the case of cricket-flour buns. PhD thesis, Jomo Kenyatta University of Agriculture and Technology, Nairobi, Kenya.

Pambo, K.O., Okello, J.J., Mbeche, R.M., Kinyuru, J.N. and Alemu, M.H., 2018. The role of product information on consumer sensory evaluation, expectations, experiences and emotions of cricket-flour buns. Food Research International 106: 532-541.

Paoletti, M.G., 2005. Ecological implications of minilivestock: potential of insects, rodents, frogs and snails. Science Publisher, Inc., Enfield, USA, $648 \mathrm{pp}$.

Peng, B.-Y., Su, Y., Chen, Z., Chen, J., Zhou, X., Benbow, M.E., Criddle, C., Wu, W.-M. and Zhang, Y., 2019. Biodegradation of polystyrene by dark (Tenebrio obscurus) and yellow (Tenebrio molitor) mealworms (Coleoptera: Tenebrionidae). Environmental Science \& Technology 53: 5256-5265. 
Perednia, D.A., Anderson, J. and Rice, A., 2017. A comparison of the greenhouse gas production of black soldier fly larvae versus aerobic microbial decomposition of an organic feed material. Journal of Ecology and Environmental Sciences 5: 10-16.

Pino Moreno, J.M., 2016. The career of Dr J. Ramos-Elorduy Blásquez. Journal of Insects as Food and Feed 2: 3-14. https://doi.org/10.3920/ JIFF2015.0079

Pinotti, L., Giromini, C., Ottoboni, M., Tretola, M. and Marchis, D., 2019. Review: insects and former foodstuffs for upgrading food waste biomasses/streams to feed ingredients for farm animals. Animal 65: 16-27.

Pisanello, D. and Caruso, G., 2018. EU regulation on novel foods, novel foods in the European Union. Springer International Publishing, Cham, Switzerland, pp. 1-29.

Pojić, M., Mišan, A. and Tiwari, B., 2018. Eco-innovative technologies for extraction of proteins for human consumption from renewable protein sources of plant origin. Trends in Food Science \& Technology 75: 93-104.

Purschke, B., Scheibelberger, R., Axmann, S., Adler, A. and Jäger, H., 2017a. Impact of substrate contamination with mycotoxins, heavy metals and pesticides on the growth performance and composition of black soldier fly larvae (Hermetia illucens) for use in the feed and food value chain. Food Additives \& Contaminants Part A 34: 1410-1420.

Purschke, B., Stegmann, T., Schreiner, M. and Jäger, H., 2017b. Pilotscale supercritical $\mathrm{CO}_{2}$ extraction of edible insect oil from Tenebrio molitor L. larvae - Influence of extraction conditions on kinetics, defatting performance and compositional properties. European Journal of Lipid Science and Technology 119: 1600134. https://doi. org/10.1002/ejlt.201600134

Putra, R.E., Hutami, R., Suantika, G. and Rosmiati, M., 2017. Application of compost produced by bioconversion of coffee husk by black soldier fly larvae (Hermetia illucens) as solid fertilizer to lettuce (Lactuca sativa var. crispa): impact to harvested biomass and utilization of nitrogen, phosphor, and potassium. Proceeding of International Conference on Green Technology 8: 20-26.

Ranta, V., Aarikka-Stenroos, L., Ritala, P. and Mäkinen, S.J., 2018. Exploring institutional drivers and barriers of the circular economy: a cross-regional comparison of China, the US, and Europe. Resources, Conservation and Recycling 135: 70-82.

Raad voor Dieraangelegenheden (RDA), 2018. The emerging insect industry: invertebrates as production animals. The Council on Animal Affairs in the Netherlands, The Hague, the Netherlands. Available at: https://tinyurl.com/y3vmhggg.

Rehman, K.U., Cai, M., Xiao, X., Zheng, L., Wang, H., Soomro, A.A., Zhou, Y., Li, W., Yu, Z. and Zhang, J., 2017. Cellulose decomposition and larval biomass production from the co-digestion of dairy manure and chicken manure by mini-livestock (Hermetia illucens L.). Journal of Environmental Management 196: 458-465.

Rehman, K.U., Rehman, R.U., Somroo, A.A., Cai, M., Zheng, L., Xiao, X., Rehman, A.U., Rehman, A., Tomberlin, J.K., Yu, Z. and Zhang, J., 2019. Enhanced bioconversion of dairy and chicken manure by the interaction of exogenous bacteria and black soldier fly larvae. Journal of Environmental Management 237: 75-83.
Richmond, E.K., Rosi, E.J., Walters, D.M., Fick, J., Hamilton, S.K., Brodin, T., Sundelin, A. and Grace, M.R., 2018. A diverse suite of pharmaceuticals contaminates stream and riparian food webs. Nature Communications 9: 4491.

Rocha Oliveira, F., Doelle, K., List, R. and O'Reilly, J.R., 2015. Assessment of Diptera: Stratiomyidae, genus Hermetia illucens (L., 1758) using electron microscopy. Journal of Entomology and Zoology Studies 3: 147-152.

Roháček, J. and Hora, M., 2013. A northernmost European record of the alien black soldier fly Hermetia illucens (Linnaeus, 1758) (Diptera: Stratiomyidae). Casopis slezskeho zemskeho muzea (A) Opava 62: 101-106.

Roncolini, A., Milanović, V., Cardinali, F., Osimani, A., Garofalo, C., Sabbatini, R., Clementi, F., Pasquini, M., Mozzon, M., Foligni, R., Raffaelli, N., Zamporlini, F., Minazzato, G., Trombetta, M.F., Van Buitenen, A., Van Campenhout, L. and Aquilanti, L., 2019. Protein fortification with mealworm (Tenebrio molitor L.) powder: effect on textural, microbiological, nutritional and sensory features of bread. PLoS ONE 14: e0211747.

Roos, N. and Van Huis, A., 2017. Consuming insects: are there health benefits? Journal of Insects as Food and Feed 3: 225-229. https:// doi.org/10.3920/JIFF2017.x007

Rosmiati, M., Nurjanah, K.A., Suantika, G. and Putra, R.E., 2017. Application of compost produced by bioconversion of coffee husk by black soldier fly larvae (Hermetia illucens) as solid fertilizer to lettuce (Lactuca aativa var. Crispa): impact to growth. Proceedings of International Conference on Green Technology 8: 38-44.

Rubio, N.R., Fish, K.D., Trimmer, B.A. and Kaplan, D.L., 2019. Possibilities for engineered insect tissue as a food source. Frontiers in Sustainable Food Systems 3: 24. https://doi.org/10.3389/ fsufs.2019.00024

Ruby, M.B. and Rozin, P., 2019. Disgust, sushi consumption, and other predictors of acceptance of insects as food by Americans and Indians. Food Quality and Preference 74: 155-162.

Rumbos, C.I., Karapanagiotidis, I.T., Mente, E. and Athanassiou, C.G., 2019. The lesser mealworm Alphitobius diaperinus: a noxious pest or a promising nutrient source? Reviews in Aquaculture, 11: 14181437. https://doi.org/10.1111/raq.12300

Rumpold, B.A., Bußler, S., Jäger, H. and Schlüter, O., 2017. Insect processing. In: Van Huis, A. and Tomberlin, J.K. (eds.) Insects as food and feed: from production to consumption, Wageningen Academic Publishers, Wageningen, the Netherlands, pp. 319-342.

Rumpold, B.A. and Langen, N., 2019. Potential of enhancing consumer acceptance of edible insects via information. Journal of Insects as Food and Feed 5: 45-53. https://doi.org/10.3920/JIFF2018.0041

Sanabria, C.O., Hogan, N.S., Madder, K.M. and Buchanan, F.C., 2017. Insect larvae fed mycotoxin-contaminated wheat - a possible safe, sustainable protein source for animal feed? Journal of Animal Science 95: 36.

Sarpong, D., Kwarteng, S.O., Gyasi, S.F., Buamah, R., Donkor, E., Botchway, E.Y. and Acquah, S., 2018. Biodegradation of heterogeneous mixture of organic fraction of municipal solid waste by black soldier fly larvae (Hermetia illucens) under the tropical climate conditions. International Journal of Innovative Science, Engineering \& Technology 5: 244-254. 
Scarlat, N., Fahl, F., Dallemand, J.-F., Monforti, F. and Motola, V., 2018. A spatial analysis of biogas potential from manure in Europe. Renewable and Sustainable Energy Reviews 94: 915-930.

Schouteten, J.J., De Steur, H., De Pelsmaeker, S., Lagast, S., Juvinal, J.G., De Bourdeaudhuij, I., Verbeke, W. and Gellynck, X., 2016. Emotional and sensory profiling of insect-, plant- and meat-based burgers under blind, expected and informed conditions. Food Quality and Preference 52: 27-31.

Sharif, R., Mujtaba, M., Ur Rahman, M., Shalmani, A., Ahmad, H., Anwar, T., Tianchan, D. and Wang, X., 2018. The multifunctional role of chitosan in horticultural crops; a review. Molecules 23: 872. https://doi.org/10.3390/molecules23040872

Sharp, G.R., 2013. A review of the applications of chitin and its derivatives in agriculture to modify plant-microbial interactions and improve crop yields. Agronomy 3: 757-793.

Sheppard, C.D., Larry Newton, G., Thompson, S.A. and Savage, S., 1994. A value added manure management system using the black soldier fly. Bioresource Technology 50: 275-279.

Shockley, M., Allan, R.N. and Gracer, D., 2017. Product development and promotion: insectarians and insect cuisine. In: Van Huis, A. and Tomberlin, J. (eds.) Insects as food and feed: from production to consumption. Wageningen Academic Publishers, Wageningen, the Netherlands, pp. 399-427.

Sipponen, M.H., Mäkinen, O.E., Rommi, K., Heiniö, R.-L., HolopainenMantila, U., Hokkanen, S., Hakala, T.K. and Nordlund, E., 2017. Biochemical and sensory characteristics of the cricket and mealworm fractions from supercritical carbon dioxide extraction and air classification. European Food Research and Technology 244: 19-29.

Skau, J.K., Touch, B., Chhoun, C., Chea, M., Unni, U.S., Makurat, J., Filteau, S., Wieringa, F.T., Dijkhuizen, M.A., Ritz, C., Wells, J.C., Berger, J., Friis, H., Michaelsen, K.F. and Roos, N., 2015. Effects of animal source food and micronutrient fortification in complementary food products on body composition, iron status, and linear growth: a randomized trial in Cambodia. The American Journal of Clinical Nutrition 101: 742-751.

Smarzyński, K., Sarbak, P., Musiał, S., Jeżowski, P., Michał Piątek and Kowalczewski, P.Ł., 2019. Nutritional analysis and evaluation of the consumer acceptance of pork pâté enriched with cricket powder preliminary study. Open Agriculture 4: 159-163.

Smetana, S., Schmitt, E. and Mathys, A., 2019. Sustainable use of Hermetia illucens insect biomass for feed and food: attributional and consequential life cycle assessment. Resources, Conservation and Recycling 144: 285-296.

Sogari, G., Menozzi, D. and Mora, C., 2018. Sensory-liking expectations and perceptions of processed and unprocessed insect products. International Journal on Food System Dynamics 9: 314-320.

Sokol, W.N., Wünschmann, S. and Agah, S., 2017. Grasshopper anaphylaxis in patients allergic to dust mite, cockroach, and crustaceans: is tropomyosin the cause? Annals of Allergy, Asthma \& Immunology 119: 91-92.

Somroo, A.A., Rehman, K.U., Zheng, L., Cai, M., Xiao, X., Hu, S., Mathys, A., Gold, M., Yu, Z. and Zhang, J., 2019. Influence of Lactobacillus buchneri on soybean curd residue co-conversion by black soldier fly larvae (Hermetia illucens) for food and feedstock production. Waste Management 86: 114-122.
Song, Y.S., Kim, M.W., Moon, C., Seo, D.J., Han Yeon, S., Jo Yong, H., Noh Mi, Y., Park, Y.K., Kim, S.A., Kim Young, W. and Jung, W.J., 2018. Extraction of chitin and chitosan from larval exuvium and whole body of edible mealworm, Tenebrio molitor. Entomological Research 48: 227-233.

Spranghers, T., Michiels, J., Vrancx, J., Ovyn, A., Eeckhout, M., De Clercq, P. and De Smet, S., 2018. Gut antimicrobial effects and nutritional value of black soldier fly (Hermetia illucens L.) prepupae for weaned piglets. Animal Feed Science and Technology 235: 33-42. Springmann, M., Clark, M., Mason-D'Croz, D., Wiebe, K., Bodirsky, B.L., Lassaletta, L., De Vries, W., Vermeulen, S.J., Herrero, M., Carlson, K.M., Jonell, M., Troell, M., DeClerck, F., Gordon, L.J., Zurayk, R., Scarborough, P., Rayner, M., Loken, B., Fanzo, J., Godfray, H.C.J., Tilman, D., Rockström, J. and Willett, W., 2018. Options for keeping the food system within environmental limits. Nature 562: 519-525.

Srinroch, C., Srisomsap, C., Chokchaichamnankit, D., Punyarit, P. and Phiriyangkul, P., 2015. Identification of novel allergen in edible insect, Gryllus bimaculatus and its cross-reactivity with Macrobrachium spp. allergens. Food Chemistry 184: 160-166.

Statista, 2019. Per capita consumption of meat in the Netherlands from 2007 to 2017 (in kilos). Available at: https://www.statista.com/ statistics/604849/consumer-spending-on-meat-in-the-netherlands.

Stephens, N., Sexton, A. and Driessen, C., 2019. Making sense of making meat: key moments in the first twenty years of tissue engineering muscle to make food. Frontiers in Sustainable Food Systems 3: 45. https://doi.org/10.3389/fsufs.2019.00045

Stull, V.J., Finer, E., Bergmans, R.S., Febvre, H.P., Longhurst, C., Manter, D.K., Patz, J.A. and Weir, T.L., 2018. Impact of edible cricket consumption on gut microbiota in healthy adults, a double-blind, randomized crossover trial. Scientific Reports 8: 10762. https:// doi.org/10.1038/s41598-018-29032-2

Suzuki, S. and Park, J., 2018. Consumer evaluation of healthy, unpleasant-tasting food and the post-taste effect of positive information. Food Quality and Preference 66: 107-110.

Tabassum, A., Abbasi, T. and Abbasi, S.A., 2016. Reducing the global environmental impact of livestock production: the minilivestock option. Journal of Cleaner Production 112: 1754-1766.

Tallentire, C.W., Mackenzie, S.G. and Kyriazakis, I., 2018. Can novel ingredients replace soybeans and reduce the environmental burdens of European livestock systems in the future? Journal of Cleaner Production 187: 338-347.

Tamer, C.E. and Çopur, Ö.U., 2014. Development of value-added products from food wastes. In: Malik, A., Erginkaya, Z., Ahmad, S. and Erten, H. (eds.) Food processing: strategies for quality assessment. Springer, New York, NY, USA, pp. 453-475.

Thévenot, A., Rivera, J.L., Wilfart, A., Maillard, F., Hassouna, M., Senga-Kiesse, T., Le Féon, S. and Aubin, J., 2018. Mealworm meal for animal feed: environmental assessment and sensitivity analysis to guide future prospects. Journal of Cleaner Production 170: 12601267.

Tingle, F.C., Mitchell, E.R. and Copeland, W.W., 1975. The soldier fly, Hermelia illucens in poultry houses in north central Florida. Journal of the Georgia Entomological Society 10: 179-183. 
Tomberlin, J.K., Van Huis, A., Benbow, M.E., Jordan, H., Astuti, D.A., Azzollini, D., Banks, I., Bava, V., Borgemeister, C., Cammack, J.A., Chapkin, R.S., Čičková, H., Crippen, T.L., Day, A., Dicke, M., Drew, D.J.W., Emhart, C., Epstein, M., Finke, M., Fischer, C.H., Gatlin, D., Grabowski, N.T., He, C., Heckman, L., Hubert, A., Jacobs, J., Josephs, J., Khanal, S.K., Kleinfinger, J.-F., Klein, G., Leach, C., Liu, Y., Newton, G.L., Olivier, R., Pechal, J.L., Picard, C.J., Rojo, S., Roncarati, A., Sheppard, C., Tarone, A.M., Verstappen, B., Vickerson, A., Yang, H., Yen, A.L., Yu, Z., Zhang, J. and Zheng, L., 2015. Protecting the environment through insect farming as a means to produce protein for use as livestock, poultry, and aquaculture feed. Journal of Insects as Food and Feed 1: 307-309. https://doi.org/10.3920/JIFF2015.0098

Tonk, M. and Vilcinskas, A., 2017. The medical potential of antimicrobial peptides from insects. Current Topics in Medicinal Chemistry 17: 554-575.

Tzompa Sosa, D.A. and Vincenzo Fogliano, V., 2017. Potential of insectderived ingredients for food applications. In: Shields, V.D.C. (ed.) Insect physiology and ecology. IntechOpen, London, UK. https:// doi.org/10.5772/67318

Tzompa-Sosa, D.A., Yi, L., Van Valenberg, H.J.F. and Lakemond, C.M.M., 2019. Four insect oils as food ingredient: physical and chemical characterisation of insect oils obtained by an aqueous oil extraction. Journal of Insects as Food and Feed, 5: 279 - 292. https://doi.org/10.3920/JIFF2018.0020

Tzompa-Sosa, D.A., Yi, L., Van Valenberg, H.J.F., Van Boekel, M.A.J.S. and Lakemond, C.M.M., 2014. Insect lipid profile: aqueous versus organic solvent-based extraction methods. Food Research International 62: 1087-1094.

US Food and Drug Administration (FDA), 2016. Hazard analysis and risk-based preventive controls for human food: guidance for industry. Center for Food Safety and Applied Nutrition. US FDA, Department of Health and Human Services, Washington, DC, USA.

Ushakova, N., Dontsov, A., Sakina, N., Brodsky, E.S., Ratnikova, I. A., Gavrilova, N.N., Bastrakov, A.I., Kozlova, A.A. and Nekrasov, R.V., 2017. Melanin properties at the different stages towards life cycle of the fly Hermetia illucens. Ukrainian Journal of Ecology 4: 424-431.

Ushakova, N.A., Dontsov, A.E., Sakina, N.L., Ratnikova, I.A., Gavrilova, N.N., Garmash, N.Y., Bastrakov, A.I. and Kozlova, A.A., 2018. Melanin and melanogenesis at different life stages in Hermetia illucens. Biology Bulletin 45: 47-50.

Van Broekhoven, S., Bastiaan-Net, S., De Jong, N.W. and Wichers, H.J., 2016. Influence of processing and in vitro digestion on the allergic cross-reactivity of three mealworm species. Food Chemistry 196: 1075-1083.

Van Broekhoven, S., Gutierrez, J.M., Rijk, T.C.D., Nijs, W.C.M.D. and Van Loon, J.J.A., 2017. Degradation and excretion of the Fusarium toxin deoxynivalenol by an edible insect, the yellow mealworm (Tenebrio molitor L.). World Mycotoxin Journal 10: 163-169. https:// doi.org/10.3920/WMJ2016.2102

Van Hal, O., De Boer, I.J.M., Muller, A., De Vries, S., Erb, K.H., Schader, C., Gerrits, W.J.J. and Van Zanten, H.H.E., 2019. Upcycling food leftovers and grass resources through livestock: impact of livestock system and productivity. Journal of Cleaner Production 219: 485496.
Van Huis, A., 2017. Did early humans consume insects? Journal of Insects as Food and Feed 3: 161-163. https://doi.org/10.3920/ JIFF2017.x006

Van Huis, A., 2018. Insects as human food. In: Rômulo, A. and Paulino de Albuquerque, U. (eds.) Ethnozoology: animals in our lives. Elsevier, Amsterdam, the Netherlands, pp. 195-213.

Van Huis, A., 2019. Manure and flies: biodegradation and/or biotransformation? Journal of Insects as Food and Feed 5: 55-58. https://doi.org/10.3920/JIFF2019.x002

Van Huis, A., Itterbeeck, J.V., Klunder, H., Mertens, E., Halloran, A., Muir, G. and Vantomme, P., 2013. Edible insects: future prospects for food and feed security. FAO Forestry Paper 171. Food and Agriculture Organization of the United Nations / Wageningen University and Research Centre, Rome / Wageningen, Italy/ the Netherlands, 187 pp. Available at: http://www.fao.org/docrep/018/ i3253e/i3253e.pdf.

Van Huis, A. and Oonincx, D.G.A.B., 2017. The environmental sustainability of insects as food and feed. A review. Agronomy for Sustainable Development 37: 43. https://doi.org/10.1007/s13593017-0452-8

Van Huis, A. and Tomberlin, J., 2017a. The potential of insects as food and feed. In: Van Huis, A. and Tomberlin, J.K. (eds.) Insects as food and feed: from production to consumption. Wageningen Academic Publishers, Wageningen, the Netherlands, pp. 25-58.

Van Huis, A. and Tomberlin, J., 2017b. Insects as food and feed: from production to consumption. Wageningen Academic Publishers, Wageningen, the Netherlands, $414 \mathrm{pp}$.

Van Lenteren, J.C., 2006. Ecosystem services to biological control of pests: why are they ignored? Proceedings of the Netherlands Entomological Society Meeting 17: 103-111.

Van Thielen, L., Vermuyten, S., Storms, B., Rumpold, B. and Van Campenhout, L., 2019. Consumer acceptance of foods containing edible insects in Belgium two years after their introduction to the market. Journal of Insects as Food and Feed 5: 35-44. https://doi. org/10.3920/JIFF2017.0075

Van Zanten, H.H.E., Bikker, P., Meerburg, B.G. and De Boer, I.J.M., 2018. Attributional versus consequential life cycle assessment and feed optimization: alternative protein sources in pig diets. The International Journal of Life Cycle Assessment 23: 1-11.

Vandeweyer, D., Milanović, V., Garofalo, C., Osimani, A., Clementi, F., Van Campenhout, L. and Aquilanti, L., 2019. Real-time PCR detection and quantification of selected transferable antibiotic resistance genes in fresh edible insects from Belgium and the Netherlands. International Journal of Food Microbiology 290: 288-295.

Vandeweyer, D., Wynants, E., Crauwels, S., Verreth, C., Viaene, N., Claes, J., Lievens, B. and Van Campenhout, L., 2018. Microbial dynamics during industrial rearing, processing, and storage of the tropical house cricket (Gryllodes sigillatus) for human consumption. Applied and Environmental Microbiology 84: e00255-18. https:// doi.org/10.1128/AEM.00255-18

Vantomme, P., 2017. Creating an enabling environment. In: Van Huis, A. and Tomberlin, J.K. (eds.) Insects as food and feed: from production to consumption. Wageningen Academic Publishers, Wageningen, the Netherlands, pp. 381-397. 
Verhoeckx, K.C., Van Broekhoven, S., Gaspari, M., Den Hartog-Jager, S.C., De Jong, G., Wichers, H., Van Hoffen, E., Houben, G. and Knulst, A.C., 2013. House dust mite (Derp 10) and shellfish allergic patients may be at risk when consuming food containing mealworm proteins. Clinical and Translational Allergy 3, Suppl. 3: 48. https:// doi.org/10.1186/2045-7022-3-S3-P48

Verhoeckx, K.C., Van Broekhoven, S., Den Hartog-Jager, C.F., Gaspari, M., De Jong, G.A.H., Wichers, H.J., Van Hoffen, E., Houben, G.F. and Knulst, A.C., 2014. House dust mite (Der p 10) and crustacean allergic patients may react to food containing yellow mealworm proteins. Food and Chemical Toxicology 65: 364-373.

Wang, H., Rehman, K.U., Liu, X. and Ziniu, Y., 2017. Insect biorefinery: a green approach for conversion of crop residues into biodiesel and protein. Biotechnology for Biofuels 10: 304. https://doi.org/10.1186/ s13068-017-0986-7

Wang, Y.S. and Shelomi, M., 2017. Review of black soldier fly (Hermetia illucens) as animal feed and human food. Foods 6: 91. https://doi. org/10.3390/foods6100091

Weinrich, R., 2018. Cross-cultural comparison between German, French and Dutch consumer preferences for meat substitutes. Sustainability 10: 1819. https://doi.org/10.3390/su10061819

Wilderspin, D.E. and Halloran, A., 2018. The effects of regulation, legislation and policy on consumption of edible insects in the global south. In: Halloran, A., Flore, R., Vantomme, P. and Roos, N. (eds.) Edible insects in sustainable food systems. Springer International Publishing, Cham, Switzerland, pp. 443-455.

Wilkinson, K., Muhlhausler, B., Motley, C., Crump, A., Bray, H. and Ankeny, R., 2018. Australian consumers' awareness and acceptance of insects as food. Insects 9: E44. https://doi.org/10.3390/ insects 9020044

Willer, H. and Lernoud, J. (eds.), 2019. The world of organic agriculture: statistics and emerging trends 2019. Research Institute of Organic Agriculture (FiBL) and IFOAM - Organics International, Frick, Switzerland.
Wynants, E., Frooninckx, L., Crauwels, S., Verreth, C., De Smet, J., Sandrock, C., Wohlfahrt, J., Van Schelt, J., Depraetere, S., Lievens, B., Van Miert, S., Claes, J. and Van Campenhout, L., 2019a. Assessing the microbiota of black soldier fly larvae (Hermetia illucens) reared on organic waste streams on four different locations at laboratory and large scale. Microbial Ecology 77: 913-930.

Wynants, E., Frooninckx, L., Van Miert, S., Geeraerd, A., Claes, J. and Van Campenhout, L., 2019b. Risks related to the presence of Salmonella sp. during rearing of mealworms (Tenebrio molitor) for food or feed: survival in the feeding substrate and transmission to the larvae. Food Control 100: 227-234.

Xiao, X., Mazza, L., Yu, Y., Cai, M., Zheng, L., Tomberlin, J.K., Yu, J., Van Huis, A., Yu, Z., Fasulo, S. and Zhang, J., 2018. Efficient coconversion process of chicken manure into protein feed and organic fertilizer by Hermetia illucens L. (Diptera: Stratiomyidae) larvae and functional bacteria. Journal of Environmental Management 217: 668-676.

Yi, L., Boekel, M.A.J.S.V. and Lakemond, C.M.M., 2016. Extracting Tenebrio molitor protein while preventing browning: effect of $\mathrm{pH}$ and $\mathrm{NaCl}$ on protein yield. Journal of Insects as Food and Feed 3: 21-31. https://doi.org/10.3920/JIFF2016.0015

Youssef, J., Keller, S. and Spence, C., 2019. Making sustainable foods (such as jellyfish) delicious. International Journal of Gastronomy and Food Science 16: 100141.

Zhang, J.B., Tomberlin, J.K., Cai, M.M., Xiao, X.P., Zheng, L.Y. and Yu, Z.N., 2020. Research and industrialisation of Hermetia illucens L. in China. Journal of Insects as Food and Feed, 6: 5-12. https://doi. org/10.3920/JIFF2019.0020.

Zimri, M.N., 2018. Preparation and electrospinning of chitosan from waste black soldier fly biomass. MSc thesis, Department of Chemistry, University of the Western Cape, South Africa. Available at: https://etd.uwc.ac.za/xmlui/handle/11394/6477. 